ADLFI. Archéologie de la France -

INFORMATIONS

Informations

une revue Gallia

Nord-Pas-de-Calais | 1989

\title{
Preux-au-Sart et Saint-Waast-la-Vallée
}

Frédéric Loridant

\section{OpenEdition \\ Journals}

Édition électronique

URL : http://journals.openedition.org/adlfi/10027

ISSN : 2114-0502

Éditeur

Ministère de la culture

Référence électronique

Frédéric Loridant, «Preux-au-Sart et Saint-Waast-la-Vallée », ADLFI. Archéologie de la France -

Informations [En ligne], Nord-Pas-de-Calais, mis en ligne le 01 mars 1997, consulté le 02 mai 2019.

URL : http://journals.openedition.org/adlfi/10027

Ce document a été généré automatiquement le 2 mai 2019.

(c) Ministère de la Culture et de la Communication, CNRS 


\title{
Preux-au-Sart et Saint-Waast-la- Vallée
}

\author{
Frédéric Loridant
}

Date de l'opération : 1989 (PI)

Inventeur(s) : Loridant Frédéric

1 L'Avesnois médiéval est très mal connu. Lors des prospections faites en novembre 1989, une maison forte et une motte ont été découvertes à Preux-au-Sart et Saint-Waast-laVallée, mais n'avaient jamais été inventoriées.

2 La maison forte (Preux-au-Sart) a été endommagée de manière fortuite au cours de la construction d'un golf. L'intervention s'est bornée à un relevé en plan et en altitude puis à une série de sondages.

3 La motte de Saint-Waast-la-Vallée, n'étant a priori pas menacée, fut seulement relevée (coupe et plan) et inventoriée.

INDEX

Index chronologique : Moyen Âge*

Index géographique : Nord-Pas-de-Calais, Nord (59), Preux-au-Sart, Saint-Waast

operation Prospection inventaire (PI) 